\title{
Effects of Blended NPSB Fertilizer on Yield and Yield Related Traits of Potato (Solanum tuberosum L.) Varieties in Oda Bultum District, Eastern Ethiopia
}

\author{
Gezahegn Assefa $^{1, *}$, Yibekal Alemayehu ${ }^{2}$, Wassu Mohammed ${ }^{2}$ \\ ${ }^{1}$ Oromia Agricultural Research Institute (IQQO), Mechara Agricultural Research Center, Mechara, Ethiopia \\ ${ }^{2}$ Department of Plant Science, Collage of Agriculture and Environmental Science, Haramaya University, Haramaya, Ethiopia
}

Email address:

gezeassefa@gmail.com (G. Assefa)

${ }^{*}$ Corresponding author

To cite this article:

Gezahegn Assefa, Yibekal Alemayehu, Wassu Mohammed. Effects of Blended NPSB Fertilizer on Yield and Yield Related Traits of Potato (Solanum tuberosum L.) Varieties in Oda Bultum District, Eastern Ethiopia. American Journal of Bioscience and Bioengineering. Vol. 9, No. 1, 2021, pp. 21-32. doi: 10.11648/j.bio.20210901.14

Received: November 22, 2020; Accepted: December 11, 2020; Published: March 22, 2020

\begin{abstract}
Potato is an important food and cash crop in eastern Ethiopia including Oda Bultum District. However, there is no information on the role of blended NPSB fertilizer required to produce tuber yield and tuber quality traits. A field experiment was conducted in Oda Bultum District, under rainfed during 2018 cropping season, with the objectives of assessing the effects of blended NPSB fertilizer rates on yield-related traits and tuber yield of potato varieties and to estimate the cost-benefit of the application of blended NPSB fertilizer in potato production. The treatments consisted of two potato varieties (Bubu and Gudanie) and six rates of NPSB (0, 100, 150, 200, 250 and $300 \mathrm{~kg}$ NPSB ha $\left.{ }^{-1}\right)$ fertilizer. The experiment was laid out as a Randomized Complete Block Design in a 6 × 2 factorial arrangement and replicated three times. Analysis of variance revealed that the two main factors; blended NPSB and variety had a significant effect on all traits except that fertilizer and variety had a non-significant effect on days to $50 \%$ emergence. Interaction of blended NPSB fertilizer and variety had a significant effect on total tuber number/hill, average tuber weight, total and marketable tuber yields $\left(\mathrm{t} \mathrm{ha}^{-1}\right)$. Gudanie variety emerged, flowered and matured earlier than Bubu. Early flowering of the crop was observed in a plot which did not receive fertilizer while the application of NPSB fertilizer delayed flowering and maturity of plants that received highest rates NPSB fertilizer $\left(200,250\right.$ and $\left.300 \mathrm{~kg} \mathrm{ha}^{-1}\right)$. The highest total tuber number hill ${ }^{-1}(16.00)$ was obtained from Gudanie variety at the application of $200 \mathrm{~kg} \mathrm{ha}^{-1}$ NPSB fertilizer. The highest proportion of small size tubers were obtained from plots than received no fertilizer while the largest proportion of large size tubers were obtained from plots that received 200, 250 and $300 \mathrm{~kg} \mathrm{ha}^{-1}$ NPSB fertilizer. The highest total and marketable tuber yields of 30.55 and $27.22 \mathrm{tha}^{-1}$, respectively were obtained from Gudanie variety with the application of $200 \mathrm{~kg} \mathrm{ha}^{-1}$ NPSB fertilizer. Gudanie had a significantly higher specific gravity $\left(1.085 \mathrm{~g} / \mathrm{cm}^{3}\right)$, tuber dry matter $(21.98 \%)$ and starch content $(15.82 \%)$ while plants produced tubers with highest specific gravity, tuber dry matter and starch content due to the application of $200 \mathrm{~kg} \mathrm{ha}^{-1}$ NPSB fertilizer. Moreover, the highest net benefit of 116,330.24 Birr ha ${ }^{-1}$ with $4066 \%$ marginal rate of return were obtained from growing of Gudanie variety with the application of $200 \mathrm{~kg} \mathrm{ha}^{-1} \mathrm{NPSB}$ plus $100 \mathrm{~kg} \mathrm{ha}^{-1}$ urea fertilizer that could be recommended for production of potato in the study area.
\end{abstract}

Keywords: Marginal Rate of Return, Marketable and Total Tuber Yield, Tuber Specific Gravity, Dry Matter Content

\section{Introduction}

Potato (Solanum tuberosum L.) is one of the most important food crops in many countries of the world. In volume of production, it is the fourth most important crop after wheat, maize and rice with annual production of 314.1 million tones cultivated on about 18.1 million hectares of land [1]. Potato is regarded as a high-potential food security crop because of its ability to provide a high yield of highquality product per unit input with a shorter crop cycle [2]. 
It is a major part of the diet of half a billion consumers in the developing countries [3]. Potato is an important food and cash crop in Eastern and Central Africa, playing a major role in national food security and nutrition, poverty alleviation and income generation, and; provides employment in the production, processing and marketing sub-sectors [4].

Potato has been introduced in to Ethiopia in 1859 by a German Botanist called Schimper. Since then, potato has become an important tuber crop in many parts of Ethiopia and it ranks first among root and tuber crops both in a volume of production and consumption followed by cassava, sweet potato, and yam where smallholder farmers are the major producers as food, and cash crop (central statistical agency [5]. Furthermore, in Ethiopia root and tuber crops covered nearly $1.63 \%$ of the area under all "meher" crops in the country [5]. Potatoes, sweet potatoes and taro/godare accounted for $29.84 \%, 22.91 \%$ and $19.72 \%$ of the total root and tuber crop area cultivated, respectively.

In Ethiopia, potato production reached 9.689 million tons from 69,610 hectares in 2017/18 cropping season as compared to 974 thousand tons from 16,000 hectares in 2001 and the number of households growing increased from 1.15 million in 2001 to over 1.19 million in "meher" 2017/18 [5]. Despite high potential production environments and marked growth, the national average potato yield in farmer's field in Ethiopia is only $13.92 \mathrm{t} \mathrm{ha}^{-1}$, which is lower than the experimental yields of over $38 \mathrm{t} \mathrm{ha}^{-1}$ done at Holeta agricultural research center and the world average of $19 \mathrm{t} \mathrm{ha}^{-1}$ [6].

Several factors limiting crop yields have been identified by many researchers in Ethiopia; the major ones are lack of stable well-adapted varieties, lack of knowledge in using optimum nutrient supply in every area of production zone, an insufficient supply of disease and insect pests' tolerant varieties [7]. Most Ethiopian soils lack most of the macro and micro nutrients that are required to sustain optimal growth and development of crops [8].

In Ethiopia, fertilizer use has increased notably since 1990 [9]. However, there is no related attainable yield increase, especially in potato [10]. This may be due to the fact that small scale farmers do not have the required resources to make or purchase fertilizer and/or the farmers do not apply the optimum amount of fertilizers rates, fertilizer types to potato varieties to harvest maximum yield from their land due to the absence of recommendation that best fit to their specific area and production system [10]. Furthermore, the highest biological and economical yield of potato was obtained from combined application of $200 \mathrm{~kg} \mathrm{ha}^{-1}$ NPSB and $92 \mathrm{~kg} \mathrm{ha}^{-1} \mathrm{~N}$ for Belete variety at Badawacho District, Hadiya Zone [11].

Chemical fertilizer sources in Ethiopian agriculture have been limited to urea and Diammonium Phosphate (DAP) over the past five decades. These types of fertilizers deliver only nitrogen and phosphorus which may not satisfy the nutrient requirements of the crops including potato in the agricultural soils. In addition, Ethiopian soil lacks most of the macro and micronutrients that are required to sustain optimal growth and development of crops [12]. Consequently, the yield of potato crops in Ethiopia is much lower than the world average production per hectare [6]. However, soil tests through the Ethio-SIS revealed that Ethiopian soils are deficient in other micronutrients like $\mathrm{B}$ and others. This is attributed to high soil erosion, removal of nutrients by crops, and continuous cropping with no replenishment of nutrients, and inadequate and unbalanced use of organic and inorganic fertilizers [13].

The Eastern area of potato production in Ethiopia mainly covers the Eastern Highlands, especially East Hararghe Zone. In West Hararghe highland, Oda Bultum District is one of the potatoes produces under rainfed and irrigation system. However, the yield of potato is low due to the absence of area and variety specific recommendation of fertilizer rates and shortages of quality seed tubers are among this many other major problems found in the area (personal communication).

In the study area, absence of area and variety specific recommendation of fertilizer rates and shortages of quality seed tubers are the causes of a large proportion of small-sized tubers production that can be categorized as unmarketable tubers and low yield. On the other hand, the soils in the area were identified to be deficient in blended fertilizer NPSB fertilizer $\left(18.9 \% \mathrm{~N}, 37.7 \% \mathrm{P}_{2} \mathrm{O}_{5}, 6.95 \% \mathrm{~S}\right.$ and $\left.0.1 \% \mathrm{~B}\right)$ which is recommended to substitute DAP fertilizer in Oda Bultum District [14]. In addition, this blended fertilizer is under distribution to be applied for all crops. Since the growth, yield and profitability of potato production is largely influenced by the fertility status of the soil and variety selection, so it is necessary to conduct research in the area to identify variety and rate of fertilizer that meets the farmers' interest to obtain high yield, tuber quality and profit from the production of potato. Therefore, the present study was conducted to assess the effect of blended NPSB fertilizer on tuber yield, yield-related and tuber quality traits of potato varieties, and to estimate cost-benefit of the application of blended NPSB fertilizer at different rates for the production of potato in Oda Bultum District.

\section{Materials and Methods}

\subsection{Description of Experimental Site}

The study was conducted under rain-fed conditions during 2018 main cropping season at Oda Baso "Kebele" Farmer Training Center (FTC) in Oda Bultum District, Eastern Ethiopia. Oda Bultum is one of the District found in West Hararghe Zone. It is located in the Eastern part of the country $362 \mathrm{~km}$ from Addis Ababa and $37 \mathrm{~km}$ from Chiro, Zonal town.

Geographically, the experimental site is located at the latitude of $8^{\circ} 54^{\prime} 0^{\prime}$ ', North and longitude of $40^{\circ} 47^{\prime} 10^{\prime}$, East (Figure 1), with an elevation of 1801 meters above sea. 


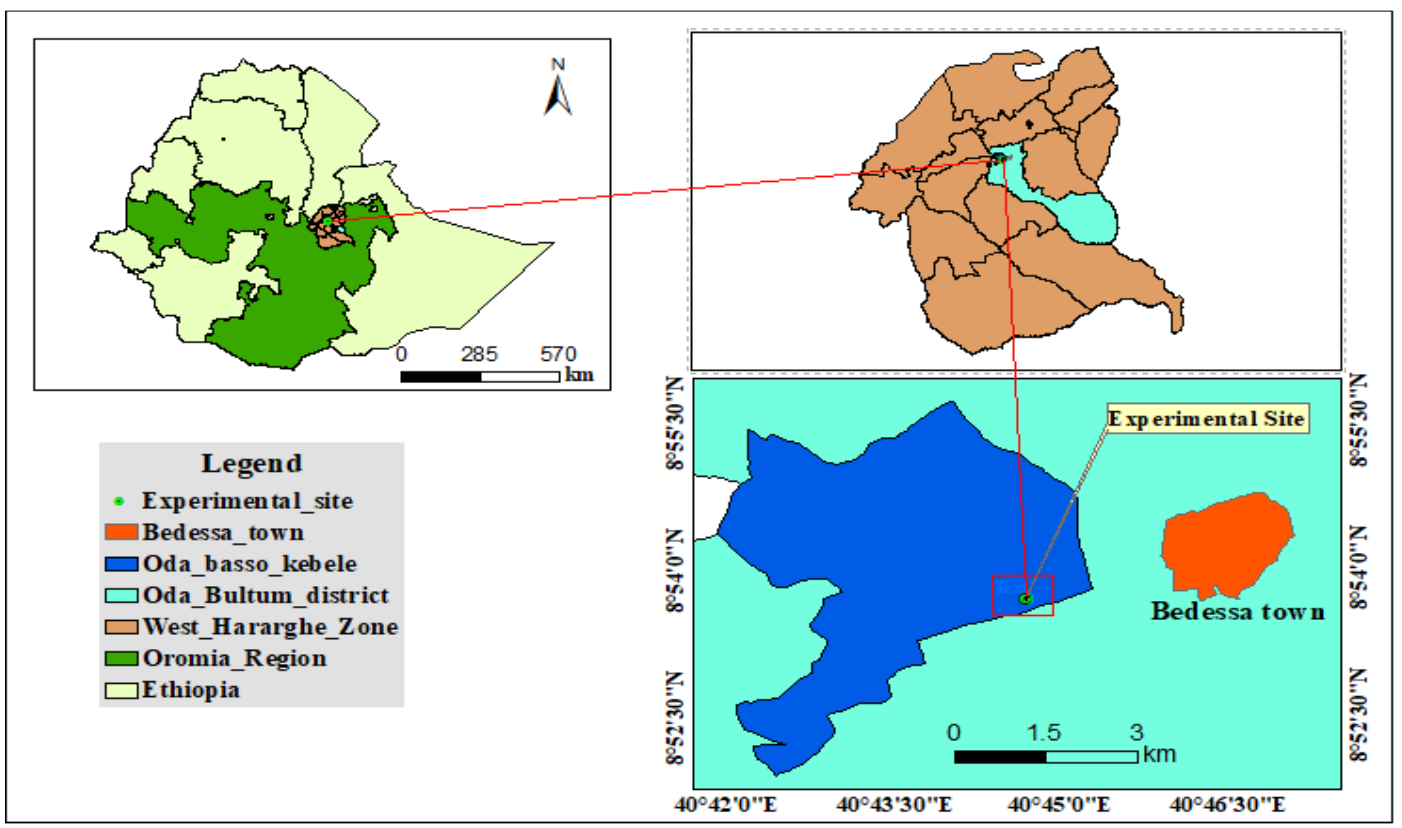

Figure 1. Map of study area.

The area has a mean annual minimum and maximum temperature of $12.23^{\circ} \mathrm{C}$ and $24.73^{\circ} \mathrm{C}$, respectively. During the $2018 / 19$ crop growing season, the total amount of rainfall received was $1261.27 \mathrm{~mm}$. However, the area received about $500.29 \mathrm{~mm}$ of total rainfall during the experimental period (July to October 2018).

The Oda Bultum District has two rainy seasons; that is, a short rainy season from the end of March to early May and a main rainy season that extends from June to September. The mean maximum temperature was about $27.69^{\circ} \mathrm{C}$ in March month. The soil is clay in texture and slightly acidic with a $\mathrm{pH}$ value of 6.27 .

\subsection{Treatments and Experimental Design}

The treatments consisted of two improved potato varieties (Bubu, and Gudanie) and six different rates of NPSB fertilizer $\left(0,100,150,200,250\right.$ and 300), plus $100 \mathrm{~kg} \mathrm{ha}^{-1}$ urea applied to all plots equally except control. Nutrients amounts in each fertilizer treatment are presented in (Table 2). The experiment was laid out as a Randomized Complete Block Design (RCBD) in a 2 x 6 factorial arrangement and replicated three times per treatment. There were 12 treatment combinations, which were assigned to each plot randomly. The total number of plots was 36 and each plot had a gross area of $16.2 \mathrm{~m}^{2}$ with $3.6 \mathrm{~m}$ length and $4.5 \mathrm{~m}$ width. Each plot contained six rows of potato plants, with each row accommodating 12 plants with a total population of 72 plants per plot at the spacing of $0.75 \mathrm{~m}$ and $0.30 \mathrm{~m}$ between rows and plants, respectively. The spacing between plots and adjacent blocks was $1 \mathrm{~m}$ and $1.5 \mathrm{~m}$, respectively. Plants in the two outer rows, as well as those at both ends of each row, were not considered for data collection to avoid edge effects.

\subsection{Experimental Procedure and Crop Management}

The experimental field was cultivated from end of April to mid July 2018 to a depth of 25 - $30 \mathrm{~cm}$ using oxen to fine soil tilth. Ridges and plots were leveled manually. Medium-sized and well-sprouted potato tubers were planted on ridges at the specified spacing by placing one tuber per hill. The tubers were planted on July 28, 2018 at the spacing of $75 \mathrm{~cm}$ between rows and $30 \mathrm{~cm}$ between seed tubers. The blended NPSB fertilizers at the specified rates were applied by banding the granules at the depth of $5 \mathrm{~cm}$ below and around the seed tuber at planting for blended NPSB fertilizer. All blended NPSB fertilizer was applied at planting, while urea fertilizer was applied in three splits $(1 / 4)$ at plant emergence, $(1 / 2)$ at the first earthing up and the remaining $(1 / 4)$ at the initiation of tubers (at the start of flowering) as per the recommendation. All urea applications were made at a time when the soil moisture is not excessively high to avoid leaching of $\mathrm{N}$. All other cultural practices were followed as per the recommendation for raising a successful crop.

\subsection{Data Collection Measurements}

Days to flowering were recorded when $50 \%$ of the plant population attained the flowering stage. Plant height was determined by measuring height from the base of the main shoot to the apex at full blooming. Number of stems per hill was recorded as the average stem count of five hills per plot reached at flowering stage. Only stems arising from the mother tuber were considered as main stems. [15]. Days to physiological maturity was recorded when the leaves of $70 \%$ of the plants in the plot turned yellowish. Tuber number and yield were represented by taking the average of 16 hills per plot.

\subsection{Data Analysis}

The data were subjected to analysis of variance (ANOVA) using Gen-Stat release $16^{\text {th }}$ Edition software [16]. The result interpretations were made following the procedure of Gomez 
and Gomez and means of significant treatment effects were separated using the Fishers' Protected Least Significant Difference (LSD) test at 5\% probability level of significance.

\subsection{Partial Budget Analysis}

The economic analysis was carried out by using the methodology described in in which prevailing market prices for inputs at planting and for outputs at harvesting were used [17]. All costs and benefits were calculated on a basis in Birr. The concepts used in the partial budget analysis were the mean marketable tuber yield of each treatment, the gross benefit $(\mathrm{GB}) \mathrm{ha}^{-1}$ (the mean marketable tuber yield for each treatment) and the field price of fertilizers (the costs purchasing of blended NPSB, application costs and cost of tuber yield transportation to the nearer market).

\section{Results and Discussion}

\subsection{Physico-chemical Properties of the Experimental Soil}

The results of the pre-sowing composite soil sample laboratory analyses indicated that the soil textural class of experimental site was $24 \%$ silt, $51 \%$ clay and $25 \%$ sand (Table 1). Thus, the texture of the soil was clay according to textural classification system [18]. The texture indicates the degree of weathering, nutrient, and water holding capacity of the soil. Furthermore, the clay soil texture was suitable for potato and other major crops production due to its good ability to retain nutrients and available water. However, clay soil has a high proportion of clay particles. It is the cause's two biggest drawbacks of soils as it swells when wet and creating difficulty to till (heavy of soils) and cracks when dry exposing the roots to the atmospheric elements [18].

The $\mathrm{pH}$ of the soil was almost slightly acidic (6.27), according to the rating of [19]. This value falls in the $\mathrm{pH}$ range that was very conducive for potato production as normal optimum soil $\mathrm{pH}$ for production is from 5.2 - 6.5 [20]. Cation Exchange Capacity (CEC) of the soil was (43.82 meq $/ 100 \mathrm{~g}$ ) which was very high according to the rating of [21]. Therefore, there could be no limitation to the growth of the potato crop in terms of this soil CEC. The total soil nitrogen content of experimental soil was $0.15 \%$ which is moderate according to [21].

The available phosphorus content of the soil was medium $(10.79 \mathrm{ppm})$ in accordance with the rating of [22]. Potato needs a good supply of readily available phosphorus since the root system is not extensive and does not readily utilize less available $\mathrm{P}$ forms.

Available sulfur $(10.77 \mathrm{ppm})$ and boron $(0.60 \mathrm{ppm})$ were low according to rating scale [23]. Thus, according to the soil laboratory results, the soil of the study area was suitable for the production of potatoes and other crops.

Table 1. Physical and chemical properties of the experimental site before-planting at Oda bultum district during in, 2018.

\begin{tabular}{|c|c|c|c|}
\hline 1. Properties (\%) & Result & Rating & References \\
\hline Sand $(\%)$ & 25 & - & - \\
\hline Silt $(\%)$ & 24 & - & - \\
\hline Clay $(\%)$ & 51 & - & - \\
\hline \multicolumn{4}{|l|}{ 2. Chemical properties } \\
\hline $\mathrm{pH}\left(1: 2.5 \mathrm{H}_{2} \mathrm{O}\right)$ & 6.27 & Slightly acidic & Tekalign (1991) \\
\hline Organic Matter /OM/ (\%) & 3.00 & Medium & Tekalign (1991) \\
\hline Carbon-Nitrogen ratio $(\mathrm{C}: \mathrm{N})$ & 9.16 & Very low & Newey (2006) \\
\hline CEC (meq/100 g soil) & 43.82 & Very high & Murphy (2007) \\
\hline Total Nitrogen /TN/ (\%) & 0.15 & Medium & Murphy (1968) \\
\hline Available Phosphorus /P/(ppm) & 10.79 & Medium & Cottenie (1980) \\
\hline Available Sulfur /S/(ppm) & 10.77 & Low & EthioSIS (2014) \\
\hline Available Boron /B/(ppm) & 0.06 & Low & EthioSIS (2014) \\
\hline
\end{tabular}

\subsection{Phenology and Growth of Potato}

\section{Phenology of potato traits}

Days to $50 \%$ tubers emergence was significantly $(\mathrm{P}<0.05)$ influenced by variety, while the two main factors viz. variety and blended NPSB fertilizer had highly significant $(\mathrm{P}<0.01)$ effect on days to $50 \%$ flowering and days to $90 \%$ maturity. The interaction of variety and blended NPSB fertilizer had a non-significant effect on phenology of potato (Table 2).

Bubu had late emergence of tubers which took average days of 12.33 after planting. This variety also had significantly delayed days to $50 \%$ flowering (52.5 days after planting) and maturity (108.72 days after planting) than Gudanie variety. Early flowering (50.33 days after planting) of the crop was observed in the plot which did not receive fertilizer while the application of NPSB fertilizer delayed both the flowering and maturity of the crop. The delayed flowering of potato was observed in plots which received 300,250 and $100 \mathrm{~kg} \mathrm{ha}^{-1}$ NPSB of fertilizer with nonsignificant differences among the treatments effects. Plants in plots which did not receive fertilizer and $100 \mathrm{~kg} \mathrm{ha}^{-1}$ NPSB fertilizer showed earliness of crop maturity while plants in all other plots that received $\left(150,200,250\right.$ and $300 \mathrm{~kg} \mathrm{ha}^{-1}$ NPSB) showed delayed maturity (Table 2). This may be related to the availability of $\mathrm{N}$ found in the soil and that may not show more difference among the treatments.

The difference in emergence and 50\% days to flowering and days to $90 \%$ maturity among the varieties may be explained by differences in the genetic characteristics. This suggestion supported by who reported a significant difference between Gudanie, Belete and Jalenie varieties for days to $50 \%$ 
emergence of plants at Degam [24]. Similar reported shown that increasing application from 0 to $350 \mathrm{~kg} \mathrm{NPSB} \mathrm{ha-1} \mathrm{did} \mathrm{not}$ show significantly difference on $50 \%$ days to emergence of potato [24]. The significant difference between two potato varieties for flowering and maturity might be explained by differences in the genetic characteristics. This suggestion supported by who reported that Gudanie variety was early to mature as compared to Bubu and Belete varieties [24].

The significant effect of higher rates of NPSB fertilizer on delayed flowering of potato and the observed trend of delayed maturity towards the application of higher rates of
NPSB fertilizer might be due to sufficient supply of nutrient that promotes vegetative growth and delayed the crop in attaining reproductive stage. These results are in agreement with, who reported that application of NPS fertilizers delayed flowering stage $[26,24]$. In addition to these results, reported that increased phosphorus application prolonged the days to $50 \%$ flowering [25]. Furthermore, application of nitrogen fertilizer at higher rates enhanced vegetative growth by helping the plant to absorb sunlight and produce carbohydrates, but delayed the production of reproductive part and thereby maturity [26].

Table 2. Effects of variety and blended NPSB fertilizer rates on the phenology of potato at Oda bultum distrct during 2018.

\begin{tabular}{llll}
\hline Treatment & Traits & & \\
\hline Variety & Days to 50\% emergence & Days to 50\% flowering & Days to 90\% maturity \\
\hline Bubu & $12.33^{\mathrm{a}}$ & $52.50^{\mathrm{a}}$ & $108.72^{\mathrm{a}}$ \\
Gudanie & $11.50^{\mathrm{b}}$ & $51.22^{\mathrm{b}}$ & $105.58^{\mathrm{b}}$ \\
LSD (5\%) & 0.37 & 0.72 & 0.81 \\
NPSB fertilizer $\left(\mathrm{kg} \mathrm{ha}^{-1}\right)$ & & & $105.10^{\mathrm{c}}$ \\
0 & 12.16 & $50.33^{\mathrm{d}}$ & $106.21^{\mathrm{ab}}$ \\
100 & 12.00 & $51.67^{\mathrm{bc}}$ & $107.20^{\mathrm{bc}}$ \\
150 & 11.50 & $51.83^{\mathrm{abc}}$ & $108.01^{\mathrm{a}}$ \\
200 & 12.00 & $51.50^{\mathrm{cd}}$ & $108.13^{\mathrm{a}}$ \\
250 & 11.83 & $52.83^{\mathrm{ab}}$ & $108.51^{\mathrm{a}}$ \\
300 & 12.00 & $53.00^{\mathrm{a}}$ & 1.41 \\
LSD (5\%) & $\mathrm{NS}$ & 1.25 & 1.1 \\
\hline
\end{tabular}

Means within column followed by the same letter (s) are not significantly different at $5 \%$ level of significance, LSD $(5 \%)=$ Least significant difference at $\mathrm{p}=$ 0.05 and $\mathrm{CV}(\%)=$ Coefficient of variation in percent

\subsection{Growth of Potato Crop}

\section{Plant height and number of main stem}

The variety and NPSB fertilizer had significant $(\mathrm{P}<0.01)$ main effect on plant height and number of main stem per hill. However, the interaction effect of the two factors was not significant on plant height and main stem number (Table 3 ).

Bubu variety had tall plants $(62.44 \mathrm{~cm})$ and higher number of main stems per hill (6.78) than Gudanie variety. Likewise, Belete (6.52) and Gudanie (6.89) produced a significantly different number of main stems per hill [25]. The differences between varieties for plant heights and number of main stems could be attributed by differences in genetic constitution of the varieties. In addition, the difference in plant height and main stem number among the varieties might be due to the inherent genotypic variation [27].

Increasing the rate of NPSB fertilizer increased plant height and main stem number per hill linearly. Application of 200, 250 and $300 \mathrm{~kg} \mathrm{NPSB} \mathrm{ha}{ }^{-1}$ fertilizer rates resulted in significantly higher plant height and main stem number. Increasing the rate of the fertilizer application from 0 to 300 $\mathrm{kg}$ NPSB ha ${ }^{-1}$ increased the plant height and of main stems number per hill by $18.58 \%$ and $100 \%$, respectively (Table 3 ). The highest plant height $(64.83 \mathrm{~cm})$ and main stem number $\left(8.33 \mathrm{hill}^{-1}\right)$ were obtained from the application of $300 \mathrm{~kg} \mathrm{ha}^{-1}$ NPSB fertilizer while the shortest plants $(54.67 \mathrm{~cm})$ and main stem number $\left(4.16\right.$ hill $\left.^{-1}\right)$ were registered at the unfertilized plot. However, the mean of plant height and main stem number were not statistically different among treatments 200 ,
250 and $300 \mathrm{~kg} \mathrm{ha}^{-1}$ NPSB fertilizer application this might be due to effect of $\mathrm{N}$ found in the soil which did not showed varies among the treatment.

The significantly tallest plants and highest number of main stems were observed towards the application of higher rates of NPSB fertilizer that might be ascribed to the increased availability of nitrogen in the soil for uptake by plant roots, which might have sufficiently enhanced vegetative growth through increasing cell division and elongation. Moreover, other studied reported that plant height is increased with increasing application of NPSB fertilizer from 0 to $350 \mathrm{~kg} \mathrm{ha}$ ${ }^{1}$ [24]. This might be presence of boron in the blended fertilizer nutrient source might significantly increased plant height due to its important role in the cell division and nitrogen absorption from the soil, enhancing plant growth ultimately increased plant height. Similarly, other research work reported that increasing the rate of phosphorus from nil to $230 \mathrm{~kg} \mathrm{P}_{2} \mathrm{O}_{5}$ ha $^{-1}$ resulted in highly significant increases in plant height [28]. It might be the presence of boron and sulfur in the blended fertilizer nutrient source also significantly increased plant height due to its important role in the cell division and nitrogen absorption from the soil, enhancing plant growth ultimately increased plant height.

In addition to these, the current investigation is also consistent with the other findings reported that significantly increased stem number per hill with increasing the level of lime and NPS fertilizer application [29]. Moreover, increasing application of NPSB fertilizer rates from 0 to 350 $\mathrm{kg}$ NPSB ha ${ }^{-1}$ was increased the main stem number of potato 
from 4.99 to 6.48 per hill, [24]. This might be related to the fact that a synergistic effect of the combined application of $\mathrm{N}$ and P promoting good root system, strong stem and good growth.

Table 3. Effects of varieties and NPSB fertilizers on potato plant height and number of main stems, at Oda bultum distrct in 2018.

\begin{tabular}{|c|c|c|}
\hline Treatment & Traits & \\
\hline Varieties & Plant height (cm) & Main stem number $\left(\right.$ hill $\left.^{-1}\right)$ \\
\hline Bubu & $62.44^{\mathrm{a}}$ & $6.78^{\mathrm{a}}$ \\
\hline Gudanie & $58.92^{\mathrm{b}}$ & $6.06^{\mathrm{b}}$ \\
\hline $\operatorname{LSD}(5 \%)$ & 1.15 & 0.41 \\
\hline \multicolumn{3}{|c|}{ NPSB fertilizer $\left(\mathrm{kg} \mathrm{ha}^{-1}\right)$} \\
\hline 0 & $54.67^{\mathrm{d}}$ & $4.16^{\mathrm{c}}$ \\
\hline 100 & $58.58^{\mathrm{cd}}$ & $5.32^{b}$ \\
\hline 200 & $61.07^{\mathrm{abc}}$ & $7.64^{\mathrm{a}}$ \\
\hline 250 & $63.67^{\mathrm{ab}}$ & $7.66^{\mathrm{a}}$ \\
\hline 300 & $64.83^{\mathrm{a}}$ & $8.33^{\mathrm{a}}$ \\
\hline $\operatorname{LSD}(5 \%)$ & 4.08 & 0.72 \\
\hline $\mathrm{CV}(\%)$ & 5.3 & 8.6 \\
\hline
\end{tabular}

Means within column followed by the same letter (s) are not significantly different at $5 \%$ level of significance, LSD $(5 \%)=$ Least significant difference at $\mathrm{p}=$ 0.05 and $\mathrm{CV}(\%)=$ Coefficient of variation in percent

\subsection{Yield Components and Tuber Yield}

Total tuber number and average tuber weight

The analysis of variance showed that the main effect of blended NPSB fertilizer and variety and their interaction effect had a significant effect $(\mathrm{p}<0.01)$ on total tuber number per hill and average tuber weight (Table 4).

The total tuber number per hill and average tuber weight ( $\mathrm{g}$ tuber $^{-1}$ ) were increased with increasing rates of NPSB from zero to 200 and 0 to $300 \mathrm{~kg} \mathrm{ha}^{-1}$ for both potato varieties, respectively (Table 4). However, increasing the NPSB supply beyond $200 \mathrm{~kg}$ NPSB level did not significantly influence the total tuber numbers per hill produced by the potato crop. Similarly, in both varieties, the lowest total tuber number per hill was obtained from plots that did not receive fertilizer. The highest total tuber number per hill (16.00 hill $\left.{ }^{-1}\right)$ and tuber weight (72.33g tuber $\left.{ }^{-1}\right)$ were obtained from the treatment combination of varieties Gudanie and Bubu for the application of $200 \mathrm{~kg}$ and $300 \mathrm{~kg}$ NPSB ha ${ }^{-1}$ rate, respectively (Table 4). However, the lowest total tuber number per hill (7.87 tuber hill $\left.{ }^{-1}\right)$ was recorded from Bubu variety with the unfertilized plot.

The results indicated that optimum rate of NPSB for maximum total tuber number was attained at $200 \mathrm{~kg}$ NPSB $\mathrm{ha}^{-1}$ for Gudanie and thus it was not agronomically necessary and beneficial to increase the rate of the fertilizer further.
Furthermore, this may be indicated that the increased $\mathrm{N}$ rate might have an inhibitory effect on tuber initiation process which increased haulm development but reduced tuber initiation. Therefore, results of the present study clearly indicated that increasing potato tuber number and mean tuber weights of potato varieties is possible up to certain level of NPSB fertilizer application rate.

Generally, the average tuber weight of potato increased as the rate of NPSB fertilizer increased. However, the maximum total tuber number per hill was attained up to $200 \mathrm{~kg}$ NPSB $\mathrm{ha}^{-1}$. The results of this study showed that the importance of NPSB application to maximize the total tuber number per hill should be kept at a moderate rather than at high rates. This result is in line with the other studied noted that the highest total tuber number per hill was obtained from $250 \mathrm{~kg}$ NPSB $\mathrm{ha}^{-1}$ [24]. Similarly, increasing the rate of the blended NPS fertilizer application from nil to $100 \mathrm{~kg} \mathrm{ha}^{-1}$ significantly increased the total tuber number per hill by about 23\% [25]. The increment of average tuber weight in response to the increased supply of blended NPSB fertilizer might be due to more fast growth, more foliage and increase in leaf area due to a higher supply of phosphorous containing fertilizer which may have induced the formation of bigger tubers thereby resulting in higher average tuber weight.

Table 4. Interaction effects of variety and blended NPSB fertilizer rates on total tuber number per hill and average tuber weight of potato at Oda bultum distrct, during in 2018.

\begin{tabular}{|c|c|c|c|c|}
\hline \multirow{3}{*}{$\begin{array}{l}\text { Blended NPSB } \\
\text { fertilizer }\left(\mathrm{kg} \mathrm{ha}^{-1}\right)\end{array}$} & \multicolumn{2}{|c|}{ Total tuber number (tuber hill $^{-1}$ ) } & \multicolumn{2}{|c|}{ Average tuber weight (g tuber $\left.{ }^{-1}\right)$} \\
\hline & \multicolumn{4}{|l|}{ Varieties } \\
\hline & Bubu & Gudanie & Bubu & Gudanie \\
\hline 0 & $7.87^{\mathrm{e}}$ & $10.20^{\mathrm{d}}$ & $56.00^{\mathrm{d}}$ & $44.67^{d}$ \\
\hline 100 & $10.00^{\mathrm{d}}$ & $12.20^{\mathrm{c}}$ & $61.00^{\mathrm{c}}$ & $59.07^{\mathrm{cd}}$ \\
\hline 150 & $12.33^{\mathrm{c}}$ & $12.20^{\mathrm{c}}$ & $63.29^{\mathrm{bc}}$ & $61.00^{\mathrm{c}}$ \\
\hline 200 & $14.06^{\mathrm{b}}$ & $16.00^{\mathrm{a}}$ & $67.33^{\mathrm{b}}$ & $66.00^{\mathrm{b}}$ \\
\hline 250 & $13.40^{\mathrm{bc}}$ & $13.20^{\mathrm{bc}}$ & $67.83^{\mathrm{ab}}$ & $66.37^{\mathrm{b}}$ \\
\hline 300 & $13.13^{\mathrm{bc}}$ & $13.04^{b c}$ & $72.33^{\mathrm{a}}$ & $66.67^{\mathrm{b}}$ \\
\hline $\operatorname{LSD}(5 \%) \mathrm{CV}(\%)$ & 1.587 .61 & & 4.734 .52 & \\
\hline
\end{tabular}

Means within column and rows of each traits followed by the same letter are not significantly different at $5 \%$ level of significance, LSD $(5 \%)=$ Least significant difference at $\mathrm{p}=0.05$ and $\mathrm{CV}(\%)=$ Coefficient of variation in percent 


\section{Distribution of tubers into size categories}

Analysis of variances revealed that percentage of small and medium tuber size were significantly $(\mathrm{p}<0.01)$ by the main effect of variety and NPSB fertilizer, while large tuber size did not affected by the main effect of variety, while the interaction of both factors is non-significant on all tuber size proportion (Table 5). From the main factors, Bubu variety had the highest medium and large tuber size was recorded with $37.27 \%$ and $31.96 \%$, respectively. Whereas, the highest small tuber size $\left(35.35 \mathrm{~g} \mathrm{tuber}^{-1}\right)$ was produced by the variety Gudanie. This may be due to the higher number of tubers as well as characteristics of variety adaptability or establishment effects of the other growth attributes. This study is in agreement with other research reported that the lowest value was obtained from Bubu variety [30].

The proportion of small-sized potato tubers significantly decreased by 53.67 to $19.94 \%$ with increasing rates of the use of mineral 0 to $300 \mathrm{~kg}$ NPSB ha ${ }^{-1}$ fertilizers, respectively. Thus, increasing application of blended NPSB fertilizer from 0 to 250 and 0 to $300 \mathrm{~kg} \mathrm{ha}^{-1}$ significantly increased the percentage of medium and large tuber size from 29.83 to $42.97 \%$ and 16.50 to $39.87 \%$, respectively (Table 8 ). On the other hand, increasing application of blended NPSB fertilizer from 0 to 250 and 0 to $300 \mathrm{~kg} \mathrm{ha}^{-1}$ significantly increased the percentage of medium and large tuber size by about $44 \%$ and $141.63 \%$, respectively. However, at higher rates of 200, 250 and $300 \mathrm{~kg}$ NPSB ha ${ }^{-1}$ fertilizer application did not significant differences observed in the proportion of medium and large-sized tubers. But there is no statistical difference from 200 to $300 \mathrm{~kg} \mathrm{NPSB} \mathrm{ha}{ }^{-1}$ (Table 5). This shows that increasing the rate of NPSB did not vigorously affect this parameter of the plant.

The result is in agreement with other studied who have demonstrated that increased phosphorus application from 46 to $138 \mathrm{P}_{2} \mathrm{O}_{5} \mathrm{~kg} \mathrm{ha}^{-1}$ increased the proportion of large and medium-sized tubers produced in the range between 49.42 to $53.72 \%$ and 36.62 to $41.26 \%$, respectively [31]. Furthermore, other scholars observed that the largest proportion of smallsized tubers was obtained at the application of unfertilized plots. Moreover, other scholar observed 34.32 to $37.53 \%$ increase of medium size tubers of potato as the NPSB application increased from 0 to $200 \mathrm{~kg} \mathrm{ha}^{-1}$ [12]. The improvement in the size of the potato tubers in response to the application of fertilizers could be ascribed to improved nutrient status and physicochemical property of the soil in the area.

Table 5. Main effects of variety and NPSB fertilizer rates on tuber size proportion of potato grown at Oda bultum during 2018.

\begin{tabular}{|c|c|c|c|}
\hline Treatment & Traits & & \\
\hline Variety & Small tuber size $(\%)$ & Medium tuber size (\%) & Large tuber size (\%) \\
\hline Bubu & $30.77^{\mathrm{b}}$ & $37.27^{\mathrm{a}}$ & 31.96 \\
\hline Gudanie & $35.35^{\mathrm{a}}$ & $34.89^{\mathrm{b}}$ & 29.77 \\
\hline $\operatorname{LSD}(5 \%)$ & 3.02 & 2.21 & NS \\
\hline \multicolumn{4}{|c|}{ NPSB fertilizer $\left(\mathrm{kg} \mathrm{ha}^{-1}\right)$} \\
\hline 0 & $53.67^{\mathrm{a}}$ & $29.83^{d}$ & $16.50^{\mathrm{c}}$ \\
\hline 100 & $42.99^{\mathrm{b}}$ & $30.28^{\mathrm{d}}$ & $26.74^{\mathrm{b}}$ \\
\hline 200 & $24.66^{\mathrm{d}}$ & $38.35^{\mathrm{bc}}$ & $36.13^{\mathrm{a}}$ \\
\hline 250 & $20.91^{\mathrm{d}}$ & $42.97^{\mathrm{a}}$ & $36.99^{\mathrm{a}}$ \\
\hline 300 & $19.94^{\mathrm{d}}$ & $40.20^{\mathrm{ab}}$ & $39.87^{\mathrm{a}}$ \\
\hline $\operatorname{LSD}(5 \%)$ & 5.23 & 3.82 & 5.32 \\
\hline $\mathrm{CV}(\%)$ & 13.4 & 9.0 & 14.6 \\
\hline
\end{tabular}

Means within column followed by the same letter (s) are not significantly different at $5 \%$ level of significance, LSD $(5 \%)=$ Least significant difference at $\mathrm{p}=$ 0.05 and $\mathrm{CV}(\%)=$ Coefficient of variation in percent

Marketable, unmarketable tuber number and Unmarketable tuber yield

Marketable tuber number was significantly $(\mathrm{P}<0.01)$ influenced by the main effects of variety and NPSB fertilizer, but not by their interaction effect (Table 6). Unmarketable tuber number hill $^{-1}$ significantly $(\mathrm{P}<0.01)$ influenced by NPSB fertilizer, but the main effect of variety did not show significance influence on unmarketable tuber number.

Gudanie had higher marketable and unmarketable tuber number of 9.36 and 3.35 tuber $^{\text {hill }}{ }^{-1}$, respectively (Table 6). This may be due to genetic differences between the varieties in photosynthesis and dry matter accumulation. Other report indicated that genetic differences among potato varieties play a role in their ability to produce high solids [32].

Marketable tuber number was increased up to $200 \mathrm{~kg}$ NPSB ha ${ }^{-1}$ rate and beyond it was decreased. Whereas the trend of unmarketable tuber was in opposite direction to as increasing application of NPSB fertilizer which decreased from zero to $300 \mathrm{~kg}$ NPSB ha ${ }^{-1}$ fertilizer application. Increasing the rate of the fertilizer application from 0 to 200 $\mathrm{kg}$ NPSB ha ${ }^{-1}$, increased marketable tuber number by about $130 \%$, however, unmarketable tuber number was decreased by $39.16 \%$. The highest marketable tuber numbers $(12.08$ tuber hill ${ }^{-1}$ ) was obtained at $200 \mathrm{~kg}$ NPSB ha- ${ }^{-1}$. Whereas, the lowest unmarketable number (2.86 tuber hill ${ }^{-1}$ ) was obtained for the application of $300 \mathrm{~kg}$ NPSB ha ${ }^{-1}$ (Table 6). Whereas, the lowest marketable tuber number (5.05 tuber hill $\left.{ }^{-1}\right)$ was recorded form unfertilized plot.

The highest marketable tuber numbers obtained by application of higher rate fertilizer might be the higher rate of nitrogen because nitrogen can activate the vegetative growth development and also associated with a decrease in the number of small size tubers due to increase in the weight of individual tubers. In addition to other studied reported that 
the application of NPSB fertilizer from 0 to $350 \mathrm{~kg}$ NPSB ha${ }^{1}$ increased the number of marketable tuber by $46 \%$ [24]. The high and lowest number of unmarketable tubers was observed for the control treatment and highest rates of fertilizer application, respectively. This may be due to the phenomenon that phosphorus increased the above-ground biomass via photosynthesis and net assimilation processes and no re-absorption evidently took place from the tubers, leading to increased tuber size and weight so the tuber could be marketable.

Table 6. Effects of variety and blended NPSB fertilizer rates on yield components at Oda bultum distrct, in 2018.

\begin{tabular}{llll}
\hline Treatment & Traits & & \\
\hline Variety & $\begin{array}{l}\text { Marketable tuber number (tuber } \\
\text { hill }^{-1} \text { ) }\end{array}$ & Unmarketable tuber number (tuber hill ${ }^{-1}$ ) & Unmarketable tuber yield (t ha $^{-1}$ ) \\
\hline Bubu & $8.51^{\mathrm{b}}$ & 3.31 & $3.17^{\mathrm{b}}$ \\
Gudanie & $9.36^{\mathrm{a}}$ & 3.59 & $3.68^{\mathrm{a}}$ \\
LSD (5\%) & 0.65 & $\mathrm{NS}$ & 0.38 \\
NPSB fertilizer $\left(\mathrm{kg} \mathrm{ha}^{-1}\right)$ & & & $3.98^{\mathrm{a}}$ \\
0 & $5.05^{\mathrm{e}}$ & $3.96^{\mathrm{a}}$ & \\
100 & $7.16^{\mathrm{d}}$ & $3.83^{\mathrm{a}}$ & \\
150 & $8.60^{\mathrm{c}}$ & $3.05^{\mathrm{b}}$ & $3.96^{\mathrm{a}}$ \\
200 & $12.08^{\mathrm{a}}$ & $2.98^{\mathrm{b}}$ & $3.95^{\mathrm{a}}$ \\
250 & $10.36^{\mathrm{b}}$ & $2.86^{\mathrm{b}}$ & $3.00^{\mathrm{b}}$ \\
300 & $10.31^{\mathrm{b}}$ & 0.70 & $2.95^{\mathrm{bc}}$ \\
LSD (5\%) & 1.13 & 17.3 & $2.30^{\mathrm{c}}$ \\
CV $(\%)$ & 10.7 & 0.66 \\
\hline
\end{tabular}

Means within column and rows of each traits followed by the same letter (s) are not significantly different at $5 \%$ level of significance, LSD (5\%) $=$ Least significant difference at $\mathrm{p}=0.05$ and $\mathrm{CV}(\%)=$ Coefficient of variation in percent

Variety, Bubu had the lowest unmarketable tuber yield (3.17 $\mathrm{t} \mathrm{ha}^{-1}$ ), while Gudanie variety had the highest unmarketable tuber yield $\left(3.68 \mathrm{t} \mathrm{ha}^{-1}\right)$. The significant difference between varieties for unmarketable yield may be due to adaptability, crop maturity, and the inherent ability of potato varieties in producing unmarketable tubers per plant. Similarly, other studied reported that Gudanie and Jalenie varieties produced significantly higher unmarketable tuber yield [33]. Furthermore, increasing NPSB blended fertilizer from 0 to $300 \mathrm{~kg}$ NPSB ha ${ }^{-1}$ decreased unmarketable tuber yield from 4.38 to $2.30 \mathrm{t} \mathrm{ha}^{-1}$. The highest unmarketable tuber yield $\left(4.38 \mathrm{t} \mathrm{ha}^{-1}\right)$ was obtained from control plot (no fertilizer applied) which was par with 100 and $200 \mathrm{~kg} \mathrm{ha}^{-1}$ NPSB fertilizer applied, whereas the lowest unmarketable tuber yield $\left(2.30 \mathrm{t} \mathrm{ha}^{-1}\right)$ was recorded from plot treated by $300 \mathrm{~kg}$ NPSB ha ${ }^{-1}$ and it was statistically par with $250 \mathrm{~kg}$ NPSB ha' ${ }^{-1}$ (Table 6).

Moreover, variety and nitrogen had a significant effect on unmarketable tuber yield of potato that increasing the nitrogen level decreased the unmarketable tuber weight up to $100 \mathrm{~kg} \mathrm{~N} \mathrm{ha}{ }^{-1}$ [34]. Similarly, other study reported that increasing the rate of blended NPS fertilizer from nil to 100 $\mathrm{kg} \mathrm{ha}^{-1}$ significantly decreased the unmarketable tuber yield [25].

\subsection{Tuber Yields}

Marketable and total tuber yields

The analysis of variance showed that the main effect of blended NPSB fertilizer and variety, as well as their interaction had significantly $(\mathrm{P}<0.05)$ influenced marketable and total tuber yields (Table 7). However, unmarketable tuber yield of potato was significantly $(\mathrm{P}<0.01)$ influenced by the main effect of variety and fertilizer but not by their interaction.
Increasing the rate of blended NPSB fertilizer from nil to $200 \mathrm{~kg} \mathrm{ha}^{-1}$ increased marketable and total tuber yield. The application of blended NPSB fertilizer increased marketable and total tuber yield (ton $\mathrm{ha}^{-1}$ ) in both potato varieties as compared to growing of varieties without fertilizer application. Increasing blended NPSB fertilizer rates from 0 to $200 \mathrm{~kg} \mathrm{ha}^{-1}$ increased marketable tuber yield of Bubu and Gudanie by about 7.83 and $11.89 \mathrm{t} \mathrm{ha}^{-1}$, respectively, whereas, it increased total tuber yield of Bubu and Gudanie 7.73 and $10.22 \mathrm{t} \mathrm{ha}^{-1}$, respectively (Table 7). Increasing the rate of the fertilizer application beyond $200 \mathrm{~kg} \mathrm{ha}^{-1}$ did not significantly increase the marketable and total tuber yields of both varieties. Thus the highest significant marketable yield $\left(27.22 \mathrm{t} \mathrm{ha}^{-1}\right)$ and total tuber yield $\left(30.55 \mathrm{t} \mathrm{ha}^{-1}\right)$ were recorded from Gudanie variety at $200 \mathrm{~kg} \mathrm{NPSB} \mathrm{ha-1}$ application, while, the lowest marketable (14.67 $\left.\mathrm{t} \mathrm{ha}^{-1}\right)$ and total yield $\left(18.43 \mathrm{t} \mathrm{ha}^{-1}\right)$ were obtained from unfertilized plots of Bubu variety.

The difference in yield among this varieties and blended NPSB fertilizer might be related to their genetic makeup in the efficient utilization of inputs like nutrients, which is one of the four major categories of the factors that affect yields (soil, climatic, genetic and management practices) the rate of nitrogen was increased from 100 to $150 \mathrm{~kg} \mathrm{~N} \mathrm{ha}^{-1}$, the marketable tuber yields of Gudanie, Jalenie and Zengena significantly increased [35].

The increase in total tuber yield in response to the increased application of the combined NPSB fertilizers might be due to the increased photosynthetic activity and translocation of photosynthetic product to the root, which might have helped in the initiation of more stolen on potato [36]. Similarly, the NPSB application beyond $200 \mathrm{~kg} \mathrm{ha}^{-1} \mathrm{did}$ not bring significant yield advantage [12]. In the current experiment, NPSB application beyond $200 \mathrm{~kg} \mathrm{ha}^{-1} \mathrm{did}$ not bring significant yield advantaged. 
Table 7. Interaction effects of blended NPSB fertilizer and variety on marketable tuber yield and total tuber yield of potato at Oda bultum distrct during, in 2018.



Means within column and rows of a variable followed by the same letter are not significantly different at $5 \%$ level of significance, LSD (5\%) $=$ Least significant difference at $\mathrm{p}=0.05$ and $\mathrm{CV}(\%)=$ Coefficient of variation in percent

\subsection{Tuber Quality Related Parameters}

The variety and NPSB fertilizer had significant $(\mathrm{P}<0.05)$ effect on specific gravity, tuber dry matter and starch contents of potato. However, the interaction effect of blended NPSB fertilizer and variety did not show significant effects on all tuber quality related traits (Table 8 ). From the main effect of variety, the higher specific gravity (1.085), tuber dry matter content $(21.98 \%)$ and tuber starch content $(15.82 \mathrm{~g} / 100 \mathrm{~g})$ were measured from Gudanie than Bubu variety (Table 8$)$.
Increasing the rates of NPSB fertilizer application from 0 to $200 \mathrm{~kg} \mathrm{ha}^{-1}$ increased the specific gravity, tuber dry matter content and tuber starch content, however, the interaction effect of blended NPSB fertilizer and variety did not show significant effects on all tuber quality related traits (Table 8), while further increase in the fertilizer rate did not bring a significant increase in these traits. Similarly, tuber starch content of the potato significantly improved by increased NPSB from 0 to $100 \mathrm{~kg} \mathrm{ha}^{-1}$, while beyond this rate the effect was non-significant.

Table 8. The main effect of varieties and blended NPSB fertilizers rates on specific gravity, tuber dry matter content and starch content of the potato at Oda bultum distrct during 2018 .

\begin{tabular}{llll}
\hline Treatment & Traits & & \\
\hline Varieties & Specific gravity of tuber $\mathbf{( g / \mathbf { c m } ^ { 3 } )}$ & Tuber dry matter content $\mathbf{( \% )}$ & Tuber starch content $(\mathbf{g} / \mathbf{1 0 0 g})$ \\
\hline Bubu & $1.081^{\mathrm{b}}$ & $21.20^{\mathrm{b}}$ & $15.19^{\mathrm{b}}$ \\
Gudanie & $1.085^{\mathrm{a}}$ & $21.98^{\mathrm{a}}$ & $15.82^{\mathrm{a}}$ \\
LSD (5\%) & 0.0020 & 0.75 & 0.61 \\
NPSB fertilizer $\left(\mathrm{kg} \mathrm{ha}^{-1}\right)$ & & & $13.64^{\mathrm{b}}$ \\
0 & $1.076^{\mathrm{c}}$ & $20.17^{\mathrm{d}}$ & $15.29^{\mathrm{a}}$ \\
100 & $1.082^{\mathrm{b}}$ & $21.27^{\mathrm{cd}}$ & $16.04^{\mathrm{a}}$ \\
150 & $1.087^{\mathrm{ab}}$ & $22.65^{\mathrm{ab}}$ & $16.31^{\mathrm{a}}$ \\
200 & $1.088^{\mathrm{a}}$ & $22.96^{\mathrm{a}}$ & $15.92^{\mathrm{a}}$ \\
250 & $1.086^{\mathrm{ab}}$ & $21.82^{\mathrm{abc}}$ & $1.82^{\mathrm{a}}$ \\
300 & $1.085^{\mathrm{ab}}$ & $21.58^{\mathrm{bc}}$ & 1.06 \\
LSD (5\%) & 0.0035 & 1.30 & 5.6 \\
CV $(\%)$ & 0.3 & 5.42 & \\
\hline
\end{tabular}

Means with in column in each trait and treatment followed by the same letter (s) are not significantly different at $5 \%$ level of significance, LSD $(5 \%)=$ Least significant difference at $\mathrm{p}=0.05$ and $\mathrm{CV}(\%)=$ Coefficient of variation in percent

The highest specific gravity (1.088), tuber dry matter content $(22.96 \%)$ and tuber starch content $(16.31 \mathrm{~g} / 100 \mathrm{~g})$ obtained from $200 \mathrm{~kg}$ NPSB ha ${ }^{-1}$. However, the lower specific gravity, tuber dry matter content and tuber starch content (1.076), (20.17\%) and (13.64g/100g) were obtained from the control plots, respectively. On the other hand, specific gravity again reverted to statistically the same value as observed at the 150 to $300 \mathrm{~kg} \mathrm{NPSB} \mathrm{ha}^{-1}$ fertilizer rates which can be probably associated with the increased stored assimilates in potato tubers with higher rates of NPSB fertilizer. This may be related to the availability of plant nutrient $\mathrm{N}$ and $\mathrm{P}$ found in the soil which may not affect strongly the traits.

Moreover, significant increase of specific gravity of potato tubers with the increased fertilizer rates, whereas also reported the highest specific gravity of tuber (1.094) of Gudanie variety due to the application of $100 \mathrm{~kg} \mathrm{NPS} \mathrm{ha}^{-1}$ fertilizer rates [22]. However, this results disagreement with other finding that specific gravity was not significantly affected by the application of blended NPSB fertilizer [24]. Therefore, increasing the rate of the mineral fertilizer beyond $200 \mathrm{~kg}$ NPSB ha ${ }^{-1}$ decreased tuber specific gravity. Furthermore, the specific gravity of potato was highly significantly influenced by NPS fertilizer rates. 
The highest tuber dry matter content (21.98\%) was recorded for Gudanie variety, while the lowest tuber dry matter $(21.20 \%)$ was obtained from Bubu variety. This might be due to the genetic difference between the varieties. In line with the result, Belete and Gudanie varieties produced tubers with higher tuber dry matter content than Bubu variety [30].

The increase of tuber dry matter with increasing up $200 \mathrm{~kg}$ NPSB application rates observed in the present study is probably the results of accumulation and partitioning of more assimilates in tubes as indicated by the findings of various researchers [38]. On the same manner, the present finding is in agreement with other, study reported that increasing application of blended fertilizers of $100 \%$ to $200 \%$ NPSB with $\mathrm{N}$ adjustment increased tuber dry matter linearly as compared to control treatment [26].

The present result appeared to be inconsistent with this finding of study reported that the chemical constituents of potato tubers like starch contents were increased with increasing the NPK levels [39]. In general, potato varieties with a starch content of $13 \%$ and above are the most preferred for processed products [40]

\subsection{Partial Budget Analysis}

The result of the partial budget analysis revealed that the maximum net benefit of Birr 116330.24 ha ${ }^{-1}$ with an acceptable marginal rate of returns (MRR) of $4066 \%$ was obtained from Gudanie variety that received the application of $200 \mathrm{~kg} \mathrm{ha}^{-1}$ blended NPSB fertilizer on (Table 9). The results of the study indicated that varieties and blended NPSB fertilizers had given promoting benefit over the control. The application of blended NPSB fertilizer for the production of tubers from both varieties had MRR above $100 \%$ but the maximum MRR (\%) was obtained from Gudanie followed from Bubu variety with the application of $200 \mathrm{~kg} \mathrm{ha}^{-1}$ blended NPSB fertilizer.

Based on this result, $200 \mathrm{~kg}$ blended NPSB ha ${ }^{-1}$ and variety Gudanie and Bubu resulted in highest adjustable marketable tuber yield 24.49 and $20.24 \mathrm{t} \mathrm{ha}^{-1}$, respectively were profitable to the farmers in the study area. The identification of a recommendation is based on a change from one treatment to another if the marginal rate of return of that change is greater than the minimum rate of return. Therefore, the Gudanie variety at different rates of blended fertilizer meets the acceptable minimum rate of return to farmers' recommendation through the best recommendation to maximize the net benefit to the farmer; therefore the highest net benefit was recorded on Gudanie variety at 200 $\mathrm{kg}$ NPSB ha ${ }^{-1}$.

Table 9. Partial budget and marginal rate of return analysis for effects of blended NPSB fertilizer rates and varieties at at Oda bultum distrct during 2018 cropping season.

\begin{tabular}{|c|c|c|c|c|c|c|c|c|}
\hline $\begin{array}{l}\text { No } \\
\text { Trt }\end{array}$ & $\begin{array}{l}\text { Blended NPSB } \\
\left(\mathrm{kg} \mathrm{ha}^{-1}\right)\end{array}$ & Variety & $\begin{array}{l}\text { Unadjusted } \\
\left.\text { Mrkyld (t ha }{ }^{-1}\right)\end{array}$ & $\begin{array}{l}\text { Adjusted Mrkyld } \\
\left(\mathrm{t} \mathrm{ha}^{-1}\right)\end{array}$ & $\begin{array}{l}\text { Total variables } \\
\text { Cost (ETB) }\end{array}$ & $\begin{array}{l}\text { Gross Income } \\
\text { (ETB) }\end{array}$ & $\begin{array}{l}\text { Net Income } \\
\text { (ETB) }\end{array}$ & $\begin{array}{l}\text { MRR } \\
(\%) \\
\end{array}$ \\
\hline 1 & 0 & B & 14.67 & 13.20 & 1584 & 66015 & 62846.6 & 0 \\
\hline 2 & 0 & G & 15.33 & 13.80 & 1656 & 68985 & 67329.4 & 606 \\
\hline 3 & 100 & B & 17.50 & 15.75 & 3500 & 78750 & 75250 & 530 \\
\hline 4 & 100 & G & 19.21 & 17.29 & 3685 & 86445 & 82760.3 & 406 \\
\hline 5 & 150 & B & 19.16 & 17.24 & 4379 & 86220 & 81840.7 & $\mathrm{D}$ \\
\hline 6 & 150 & G & 18.80 & 16.92 & 4340 & 84600 & 80259.6 & $\mathrm{D}$ \\
\hline 7 & 200 & B & 22.49 & 20.24 & 5649 & 101205 & 95556.1 & 1169 \\
\hline 8 & 200 & G & 27.22 & 24.50 & 6160 & 122490 & 116330 & 4066 \\
\hline 9 & 250 & B & 22.50 & 20.25 & 6154 & 101250 & 95096.4 & $\mathrm{D}$ \\
\hline 10 & 250 & G & 23.12 & 20.81 & 6304 & 102240 & 95936.2 & 556 \\
\hline 11 & 300 & B & 21.33 & 19.20 & 7260 & 95975 & 88715 & $\mathrm{D}$ \\
\hline 12 & 300 & G & 22.72 & 20.45 & 7327 & 104040 & 96713 & 1194 \\
\hline
\end{tabular}

Where, Blended NPSB cost $=$ Birr $12.6 \mathrm{~kg}^{-1}$ blended NPSB, blended NPSB fertilizers application cost, Birr $3.5 \mathrm{~kg}^{-1}$ of blended NPSB, Application cost of blended NPSB fertilizers 5 persons $100 \mathrm{~kg} \mathrm{ha}^{-1}$, each $70 \mathrm{ETB}$ day ${ }^{-1}$, Cost of tuber yield transportation to the near market 120 Birr ton ${ }^{-1}$ and Price of tuber yield 5 Birr kg $^{-1}$, Mrkyld = Marketable tuber yield, MRR $(\%)=$ Marginal rate of return and $\mathrm{D}=$ Dominated treatment, $\mathrm{B}=\mathrm{Bubu}, \mathrm{G}=\mathrm{Gudanie}$.

\section{Summary and Conclusion}

The results of analysis of variance indicated that Gudanie variety took a shorter time for tuber emergence, flowering and maturity than Bubu variety. Gudanie variety was grown with the application of $200 \mathrm{~kg} \mathrm{ha}^{-1}$ and Bubu variety at 300 $\mathrm{kg} \mathrm{ha}^{-1}$ NPSB of fertilizer produced significantly the highest total number of tubers and average tuber weight, respectively. Gudanie variety had significantly higher number of marketable tuber $\left(\right.$ hill $\left.^{-1}\right)$. The application of $200 \mathrm{~kg} \mathrm{ha}^{-1}$ NPSB of fertilizer produced significantly the highest number of marketable tuber though mean values had non-significant difference with the application of 250 and $300 \mathrm{~kg} \mathrm{ha}^{-1} \mathrm{NPSB}$ of fertilizer.

The highest marketable tuber yield $\left(27.22 \mathrm{t} \mathrm{ha}^{-1}\right)$ was recorded for Gudanie in response to the application of $200 \mathrm{~kg}$ NPSB ha ${ }^{-1}$ and the lowest marketable tuber yield (14.67 $\mathrm{t}$ ha$\left.{ }^{1}\right)$ was recorded for the Bubu variety with no NPSB fertilization. With the same trend, the highest total tuber yield (30.55 $\mathrm{t} \mathrm{ha}^{-1}$ ) was recorded for Gudanie in response to the application of $200 \mathrm{~kg}$ NPSB ha ${ }^{-1}$ and the lowest total tuber yield $\left(18.43 \mathrm{tha}^{-1}\right)$ was recorded for the Bubu variety with no NPSB fertilization.

The application of $200 \mathrm{~kg} \mathrm{ha}^{-1}$ NPSB plus $100 \mathrm{~kg} \mathrm{ha}^{-1}$ urea fertilizer with the combination of variety Gudanie had produced highest mean values for most of growth traits, yield 
components and tuber quality related traits. Moreover, the partial budget analysis revealed that the maximum net benefit of 116330.24 Birr ha $^{-1}$ with marginal rate of returns (MRR) of $4066 \%$ was obtained from the treatment combination of Gudanie variety and blended $200 \mathrm{~kg} \mathrm{ha}^{-1}$ NPSB fertilizer application plus $100 \mathrm{~kg} \mathrm{ha}^{-1}$ urea. Therefore, it can be concluded that $200 \mathrm{~kg} \mathrm{ha}^{-1}$ blended NPSB fertilizer rates and Gudanie variety can be provisionally recommended for potato growers in the study area.

\section{References}

[1] Adane Hirpa, Miranda, P. M, Agajie Tesfaye, Willemien, J. M, Lommen, Alfons Oude Lansink, Admasu Tsegaye and Paul, C. S. 2010. Analysis of seed potato systems in Ethiopia. American Journal of Potato Research, 87: 537-552.

[2] Mondal, M. A. A. 2003. Improvement of potato (Solanum tuberosum L.) through hybridization and in vitro culture technique. PhD. A dissertation presented to Rajshahi University, Rajshahi, Bangladesh, p 270.

[3] Lung'aho, C., Berga, B, Nyongesa, M, Gildermacher, P, Kinyale, P, Demo, P, and Kabira J. 2007. Commercial seed potato production in Eastern and Central Africa. Kenya Agricultural Institute, p. 140.

[4] CSA (Central Statistical Agency Ethiopia). 2018. Report on area and production of major crops. Agricultural sample survey. Addis Ababa Statistical Bulletin, 1 (584), 14-68.

[5] FAOSTAT (Food and Agriculture Organization). 2017. Agricultural in the world top country of potato producer area and production of major tables of Central Statistical Agency, Available online accessed at www.potato.org.

[6] Tesfaye Abebe and Yigzaw, Desalegn. 2008. Review of crop improvement research achievements and future focus in parts of western Amhara region: the case of Adet. https://pdfs.semanticscholar.org.

[7] Melkamu Alemayehu, Minwyelet Jemberie. 2018. Optimum rates of NPS fertilizer application for economically profitable production of potato varieties at Koga Irrigation Scheme, Northwestern Ethiopia. Cogent Food and Agriculture, 4: 1-17.

[8] Mulat Demeke, Kelly, V, Jayne, T. S, Ali, S. Le, Vallee, J. C. and Chen, H. 1998. Agricultural market performance and determinants of fertiliser use in Ethiopia. pp. 1-69. Working paper 10. Grain market research project. Ministry of Economic Development and Cooperation, Addis Ababa, Ethiopia.

[9] Haverkort, A. J., Van Koesveld, M. J, Schepers, H. T. A. M, Wijnands, J. H. M, Wustman, R. and Zhang, X. X. 2012. Potato prospects for Ethiopia: on the road to value addition (No. 528). PPO AGV.

[10] Biruk Namena. 2018. Effects of Rates of Blended NPSB and Nitrogen Fertilizers on Yield and Yield Components of Potato (Solanum tuberosum L) In East Badawacho District, Southern Ethiopia. MSc Thesis, Haramaya University, Haramaya, Ethiopia.

[11] Alam, M. N., Jahan, M. S. Ali, M. K. Ashraf, M. A. and Islam, M. 2007. Effect of vermicompost and chemical fertilizers on growth, yield and yield components of potato in baring soils of Bangladesh. Journal of Applied Sciences Research, 3 (12): 1879-1888.

[12] Wassie Haile and Tekalign Mamo. 2013. The Effect of Potassium on the Yields of Potato and Wheat grown on the Acidic Soils of Chencha and Hagere Selam in Southern Ethiopia. International Potash Institute, (35), pp. 3-8.

[13] ATA (Agricultural Transformation Agency). 2016. Transforming the use of fertilizer in Ethiopia: Launching the national fertilizer blending program, Addis Ababa.

[14] CIP (International Potato Center). 2006. Procedures for standard evaluation trials of advanced potato clones. An International Cooperators Guide. www.cipotato.org.

[15] Gen-Stat. 2014. Gen Stat Procedures Library Release. $16^{\text {th }}$ Edition VSN International Ltd.

[16] CIMMYT. 1988. from agronomic data to farmer recommendations: An economics training manual. Retrieved from bitstream/handle/10883/830/ 13803 .

[17] USDA (United State Department of Agriculture). 2015. Natural resources conservation service, examination and description of soil profiles. Online at: https://www.nrcs.usda.gov/wps/portal/nrcs/detail/soils/ref/?cid $=$ nrcs142p2-054253. [Accessed 13 August 2019].

[18] Tekalign Mamo, Tekalign Tadese and Aduayi E. A. 1991. Soil, plant, water, fertilizer, animal manure and compost analysis manual. Plant Science Division Working Document 13, ILCA, Addis Ababa, Ethiopia.

[19] Fageria, N. K, Baligar V. C, and Jones C. A. 2011. Growth and Mineral Nutrition of Field Crops. $3^{\text {rd }}$ Edition. Taylor \& Francis Group, NY, pp 530.

[20] Murphy, H. F. 1968. A Report on Fertility Status and Other Data on Some Soils of Ethiopia. Experimental Station Bulletin No. 44. College of Agriculture Dire Dawa, Ethiopia. 551 p.

[21] Cottenie, A. (1980). Soil and plant testing as basis of fertilizer recommendation. FAO soil bulletin 38/2. Food and Agricultural organization of the united nation, Rome.

[22] EthioSIS (Ethiopian Soil Information System). 2014. Ethiopia Soil Information System. Ethiopian Agricultural Transformation Agency. Available at: http://www.ata.gov.et/projects/ethiopian-soil-informationsystemethiosis/

[23] Muluneh Siraj. 2018. Effects of Blended NPSB Fertilizer Rates on Growth, Yield and Yield Related Traits of Potato (Solanum tuberosum L.) Varieties under Irrigation in Degem District, Central Highland of Ethiopia. MSc Thesis, Haramaya University, Haramaya, Ethiopia.

[24] Getachew Kahsay. 2016. Response of Potato (Solanum tuberosum L.) Varieties to Nitrogen and Blended Fertilizers under Irrigation at Maichew, Southern Tigray, Ethiopia. An M. Sc Thesis, Haramaya University, Haramaya, Ethiopia.

[25] Desta Bekele. 2018. Evaluation of blended and non-blended fertilizer types and rates on potato (Solanum tuberosum L.) yield and yield components at Assosa, Western Ethiopia. MSc. Thesis, Hawasa University, Hawasa.

[26] Tantowijoyo, W., Van de Fliert, E. 2006. All about Potatoes a Handbook to the Ecology and Integrated Management of Potato. International Potato Centre. 6p. 
[27] Halivin, J. L, Beaton, J. D, Tisdale S. L. and Nelson, W. L. 2003. Soil fertility and fertilizers. An introduction to nutrient management $6^{\text {th }}$ ed. Pearson Education, Inc., 88-92pp.

[28] Habtam Setu. 2012. Response of Potato (Solanum tuberosum L.) to the application of Phosphorus and Potassium fertilizers at Assosa, Benishangul Gumuz Regional State, Western Ethiopia. MSc Thesis, Haramaya University, Haramaya, Ethiopia.

[29] Minwyelet Jemberie. 2017. Effects of NPS fertilizer rate and Irrigation frequency determination method on the growth and tuber yield of Potato (Solanum tuberosum L.) in Koga Irrigation Scheme, West Gojjam, and North-Western Ethiopia. An M. Sc Thesis Presented to School of Graduate Study of Bahir Dar University, Ethiopia Bahir Dar University, 6 (4): 20-34.

[30] Hailu Muleta, Nugusie Dechassa and Jamal Abdulahi. 2019. Response of Improved and Local Potato (Solanum tuberosum L.). Cultivars to Nitrogen Fertilizer. International Journal of Food \& Nutrition, 2 (1): 1-17.

[31] Nebiya Jibril. 2016. Effect of depth and rate of phosphorus fertilizer application on yield and yield related traits of potato at Haramaya, eastern Ethiopia. MSc Thesis, Haramaya University, Haramaya.

[32] Fernandes, A. M., Soratto, R. P., and Gonsales, J. R. 2014. Root morphology and phosphorus uptake by potato cultivars grown under deficient and sufficient phosphorus supply. Horticulture Science. 180: 190-198. doi: 10.1016/j.scienta.10.035.

[33] Girma Chala, and Niguisse Dechassa. 2015. Performance of potato (Solanum tuberosum L.) cultivars and spacing at different in central highlands of Ethiopia. Ethiopian Journal Applied Science Technology, 6 (1): 23-47.
[34] Assefa Nuru. 2005. Response of two improved potato varieties to nitrogen and phosphorus application. MSc Thesis, Haramaya University, Haramaya, Ethiopia.

[35] Fikre Dessie. 2012. Influence of Nitrogen Supply on Yield and Yield Components of Potato Cultivars (Solanum tuberosum L.) and Nitrogen use Efficiency of the Cultivars at Debark District, North Western Ethiopia MSc Thesis, Haramaya University, Haramaya, Ethiopia.

[36] Karenlampi, S. O. and White, P. J. 2009. Potato proteins, lipids, and minerals. pp. 99-125. In: Singh, J and Kaur, L. (ed.). Advances in Potato Biochemistry. Elsevier Academic Publishers. Maryland, USA.

[37] Tesfaye Abebe, Wongchaochant, S., and Taychasinpitak, T. 2013. Evaluation of specific gravity of potato varieties in Ethiopia as a criterion for determining processing quality. Kasetsart Journal of Natural Science, 47, 30-41.

[38] Amin Ababiya. 2018. Integrated Use of NPS Blended Fertilizer and Cattle Manure for Growth, Yield and Quality of Potato (Solanum tuberosum L.) under Dabo Ghibe, Kebele, Seka Woreda of Jimma Zone, Southwest Ethiopia. MSc Thesis, Jimma University, Jimma, Ethiopia.

[39] Eleiwa, E. M, Ibrahim, S. A. and Mohamed, F. M. 2012. The combined effect of NPK levels and foliar nutritional compounds on growth and yield parameters of potato plants (Solanum tuberosum L.). African Journal of Microbiology Research, 6 (24): 5100-5109. DOI: 10.5897/AJMR12.085.

[40] Kirkman, M. A. 2007. Global markets for processed potato products. pp. 27-44. In: Vreugdenhil, D. (ed.). Potato Biology and Biotechnology Advances and Perspectives. Elsevier, Oxford, UK. 